\title{
Intravaginal instillation of gonadotropin-releasing hormone analogues with an absorption enhancer induced a surge of luteinizing hormone in lactating dairy cows
}

\author{
R. Wijma, M. L. Stangaferro, M. Masello, M. A. Elmetwally, ${ }^{1}$ G. E. Granados, F. Amovilli, and J. O. Giordano ${ }^{2}$ \\ Department of Animal Science, Cornell University, Ithaca, NY 14853
}

\begin{abstract}
Our objectives were to evaluate circulating LH concentrations after intravaginal (IVG) instillation of $\mathrm{GnRH}$ analogs in lactating dairy cows. In 2 experiments, lactating Holstein cows (experiment $1: \mathrm{n}=32$; experiment $2: \mathrm{n}=47$ ) received the experimental treatments $48 \mathrm{~h}$ after the first of $2 \mathrm{PGF}_{2 \alpha}$ treatments given $12 \mathrm{~h}$ apart and $7 \mathrm{~d}$ after a modified Ovsynch protocol $(\mathrm{GnRH}$ at $-7 \mathrm{~d}, \mathrm{PGF}_{2 \alpha}$ at $-24 \mathrm{~h}, \mathrm{PGF}_{2 \alpha}$ at $-56 \mathrm{~h}, \mathrm{GnRH}$ at 0 h). In experiment 1 , cows were stratified by parity and randomly allocated to receive the following treatments: $2 \mathrm{~mL}$ of saline IVG (SAL, $\mathrm{n}=6$ ), $100 \mu \mathrm{g}$ of gonadorelin (Gon) i.m. (G100-IM, $\mathrm{n}=5$ ), and $100(\mathrm{G} 100, \mathrm{n}=7$ ), $500(\mathrm{G} 500, \mathrm{n}=8)$, or $1,000 \mu \mathrm{g}$ of Gon IVG (G1000, n $=7)$. In experiment 2 , treatments were $\operatorname{SAL}(\mathrm{n}=8)$, G100-IM ( $\mathrm{n}=8)$, G1000 ( $\mathrm{n}=7), 1,000 \mu \mathrm{g}$ of Gon plus $10 \%$ citric acid (CA) IVG (G1000CA, $\mathrm{n}=8), 80 \mu \mathrm{g}$ of buserelin IVG $(\mathrm{B} 80, \mathrm{n}=8)$, and $80 \mu \mathrm{g}$ of buserelin plus $10 \%$ CA IVG (B80CA, $\mathrm{n}=8$ ). In both experiments, blood was collected every $15 \mathrm{~min}$ from $-15 \mathrm{~min}$ to $4 \mathrm{~h}$, and every $30 \mathrm{~min}$ from 4 to $6 \mathrm{~h}$ after treatment. Data for area under the curve (AUC), mean LH concentrations, and time to maximum LH concentration were analyzed by ANOVA with (mean LH only) or without repeated measures using PROC MIXED of SAS (version 9.4, SAS Institute Inc., Cary, NC). The proportion of cows with a surge of LH was evaluated with Fisher's exact test using PROC FREQ of SAS. In both experiments, LH concentrations were affected by treatment, time, and the treatment by time interaction. In experiment 1 , the AUC for LH and maximum LH concentration were greatest for the G100-IM treatment and were greater for the G1000 than for the SAL and G500 treatments. The proportion of cows with an observed surge of LH was 100 and $0 \%$ for cows that received Gon i.m. and IVG, respectively. In experiment 2 , the AUC and maxi-
\end{abstract}

\footnotetext{
Received December 24, 2016.

Accepted May 20, 2017.

${ }^{1}$ Current address: Faculty Veterinary Medicine, Mansoura

University, Mansoura, Egypt.

${ }^{2}$ Corresponding author: jog $25 @$ cornell.edu
}

mum LH concentrations were greater for the G100-IM, G1000CA, and B80CA treatments than for the other IVG treatments. The proportion of cows with a surge of LH differed by treatment $(\mathrm{SAL}=0 \%, \mathrm{G} 100-\mathrm{IM}=$ $100 \%, \mathrm{G} 1000=14 \%, \mathrm{G} 1000 \mathrm{CA}=88 \%, \mathrm{~B} 80=13 \%$, and $\mathrm{B} 80 \mathrm{CA}=100 \%)$. For the treatments with a surge of LH, time to maximum concentration of LH was the shortest for the G100-IM treatment, intermediate for the G1000CA treatment, and the longest for cows in the B80CA treatment. In conclusion, Gon (up to 1,000 $\mu \mathrm{g})$ absorption through intact vaginal epithelium after a single IVG instillation was insufficient to elicit a surge of LH of normal magnitude. Conversely, IVG instillation of $1,000 \mu \mathrm{g}$ of Gon and $80 \mu \mathrm{g}$ of buserelin with the addition of citric acid as absorption enhancer resulted in a surge of LH of similar characteristics than that induced after i.m. injection of $100 \mu \mathrm{g}$ of Gon.

Key words: intravaginal, gonadotropin-releasing hormone analogue, citric acid, luteinizing hormone surge

\section{INTRODUCTION}

Timed AI is one of the most widely used biotechnologies in cattle operations around the world (Lamb et al., 2010; Wiltbank and Pursley, 2014). In dairy farms, systematic implementation of synchronization of ovulation protocols ensures timely insemination (Pursley et al., 1997; Fricke et al., 2003) and improves fertility outcomes (Moreira et al., 2001; Souza et al., 2008; Giordano et al., 2012b). Synchronization of ovulation protocols are continuously evolving to optimize follicle development, luteal regression, timing of ovulation, and the endocrine environment before and after timed AI. As a result, groups of cows must receive hormonal treatments on multiple days of the week and different times of the day, which may reduce protocol compliance and success in farms without appropriate facilities, frequent access to animals, and availability of qualified labor. Frequent cow manipulation also disrupts time budgets and normal behavior. Thus, fully automated hormone delivery systems may be an alternative to in- 
dividual injections for facilitating implementation and improving compliance with synchronization of ovulation protocols. Automating hormone delivery may also allow designing more effective treatments or treatments tailored to individual or subgroups of cows based on their physiological or health status.

Ideally, the body cavity to insert and hold an automated hormone delivery system should allow holding the device for prolonged periods of time and easy access to the device for removal after use. Because the vagina meets these criteria, fully automated electronically controlled intravaginal (IVG) drug delivery devices have been described (Rathbone et al., 1998; Cross et al., 2004; Künnemeyer et al., 2004) and could be developed for use in cattle. Another important attribute of a body cavity to insert an automated hormone delivery device is to allow proper absorption of hormones to elicit the desired physiological response. Although sustained release of progesterone (P4) through nonautomated delivery devices has been extensively studied and is currently used in synchronization of estrus and ovulation protocols (Macmillan et al., 1991; Macmillan and Peterson, 1993; Chebel et al., 2006), the feasibility of IVG administration of important reproductive hormones, such as GnRH and $\mathrm{PGF}_{2 \alpha}$, has rarely been studied and IVG administration is not currently used in cattle. Beyond potential differences in molecular structure that may affect IVG absorption, a fundamental difference between IVG treatments with $\mathrm{P} 4$ and hormones such as $\mathrm{GnRH}$ and $\mathrm{PGF}_{2 \alpha}$ is that the former can effectively exert its biological function through sustained release because an acute effect is not necessary. Conversely, administration of exogenous GnRH is only effective to induce a surge of $\mathrm{LH}$ and $\mathrm{PGF}_{2 \alpha}$ to trigger luteolysis through immediate absorption and an acute effect on their target tissues (i.e., pituitary gland for $\mathrm{GnRH}$ and corpus luteum for $\left.\mathrm{PGF}_{2 \alpha}\right)$.

The feasibility of inducing a surge of LH of similar magnitude after IVG than i.m. administration of GnRH or its analogs has been previously studied in other species, such as the sow (Stewart et al., 2010), the rat (Okada et al., 1982, 1983), and the rabbit (Viudes-deCastro et al., 2007), but not in cattle. Although GnRH absorption through epithelial walls can occur through transmembrane diffusion, vesicle receptor-mediated transport, or paracellular diffusion (Richardson and Illum, 1992), vaginal absorption may be challenging. Transmembrane transport is probably limited due to the hydrophilic nature of $\mathrm{GnRH}$, and a receptor-mediated transport mechanism in the vaginal epithelium seems unlikely. Further, paracellular transport may be limited by intercellular apical junction complexes (Hus- sain and Ahsan, 2005) formed by tight junctions and adherens junctions (Ivanov et al., 2005).

To overcome challenges associated with absorption efficiency of molecules through intact tissues, absorption enhancers can be included to disrupt the integrity of intercellular junctions so that paracellular transport increases (Okada et al., 1982, 1983; Fatakdawala and Uhland, 2011). For example, using a rat model, Okada et al. $(1982,1983)$ observed an increase in absorption and vaginal permeability to leuprolide (i.e., a $\mathrm{GnRH}$ analog) when including citric acid in the vehicle. Carboxylic acids, such as citric acid, chelate calcium, which has been shown to loosen intercellular tight junctions, thus facilitating intercellular transport of molecules (Cho et al., 1989). In addition to absorption enhancers, a potential strategy to increase the efficacy of hormones administered through the IVG route may be the use of more potent hormone analogs. Although absorption of all analogs may be equally compromised, more potent analogs could be more effective because smaller amounts are needed to elicit a satisfactory physiological response. In the case of GnRH, multiple analogs of varying potency are available. For example, buserelin has been shown to be up to 50 times more potent than gonadorelin (Chenault et al., 1990; Picard-Hagen et al., 2015), thereby buserelin may be an alternative to gonadorelin for IVG administration.

We performed 2 experiments to evaluate the feasibility of inducing a surge of LH after IVG instillation of $\mathrm{GnRH}$ analogs in lactating dairy cows. We aimed to determine if it was possible to induce a surge of LH of similar magnitude, timing, and duration after IVG instillation of GnRH analogs as after i.m. injection of the labeled dose of gonadorelin to induce ovulation in cattle (i.e., $100 \mu \mathrm{g}$ ). Specifically, the objective of experiment 1 was to compare circulating LH concentrations after IVG instillation of different doses of the GnRH analog gonadorelin. We hypothesized that IVG instillation of gonadorelin would induce a surge of LH similar to that observed after i.m. injection of $100 \mu \mathrm{g}$ of gonadorelin. Also, we hypothesized that instillation of greater doses of gonadorelin would result in greater circulating LH concentrations. Based on the results of experiment 1, we conducted a second experiment to evaluate LH concentrations after IVG instillation of gonadorelin or buserelin with or without the inclusion of citric acid as an absorption enhancer. We hypothesized that the inclusion of citric acid to the GnRH solution and the use of a GnRH analog of greater potency than gonadorelin (i.e., buserelin) would result in a surge of LH similar to that observed after i.m. injection of 100 $\mu \mathrm{g}$ of gonadorelin. 


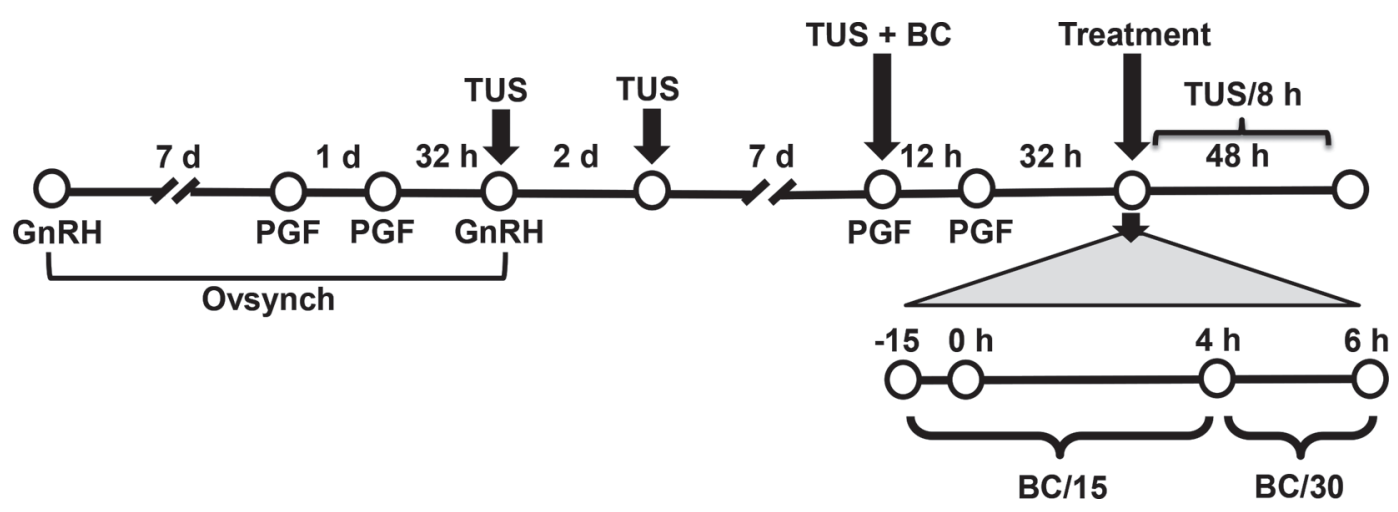

Figure 1. Graphical depiction of experimental procedures for experiments 1 and 2. Cows were synchronized using a modified Ovsynch protocol with $2 \mathrm{PGF}_{2 \alpha}$ injections ( $\mathrm{GnRH}$ at $-7 \mathrm{~d}, \mathrm{PGF}_{2 \alpha}$ at $-1 \mathrm{~d}, \mathrm{PGF}_{2 \alpha}$ at $-32 \mathrm{~h}, \mathrm{GnRH}$ at $0 \mathrm{~h}$ ). Cows with at least 1 corpus luteum $\geq 15 \mathrm{~mm}$ and 1 follicle $\geq 15 \mathrm{~mm} 7 \mathrm{~d}$ after the second GnRH injection of Ovsynch remained in the study to receive the treatments. In experiment 1 , cows $(\mathrm{n}=32)$ stratified by parity received $2 \mathrm{~mL}$ of saline solution intravaginally (SAL, $\mathrm{n}=6$ ), an i.m. injection of $100 \mu \mathrm{g}$ of gonadorelin (G100-IM, $\mathrm{n}=5), 100 \mu \mathrm{g}$ of gonadorelin intravaginally $(\mathrm{G} 100, \mathrm{n}=6), 500 \mu \mathrm{g}$ of gonadorelin intravaginally $(\mathrm{G} 500, \mathrm{n}=8)$, and $1,000 \mu \mathrm{g}$ of gonadorelin intravaginally $(\mathrm{G} 1000, \mathrm{n}=7)$. In experiment 2 , cows $(\mathrm{n}=47)$ stratified by parity received $2 \mathrm{~mL}$ of saline solution intravaginally $(\mathrm{SAL}, \mathrm{n}=$ 8), an i.m. injection of $100 \mu \mathrm{g}$ of gonadorelin (G100-IM, $\mathrm{n}=8), 1,000 \mu \mathrm{g}$ of gonadorelin intravaginally $(\mathrm{G} 1000, \mathrm{n}=7), 1,000 \mu \mathrm{g}$ of gonadorelin plus $10 \%$ citric acid intravaginal (G1000CA, $\mathrm{n}=8), 80 \mu \mathrm{g}$ of buserelin intravaginally $(\mathrm{B} 80, \mathrm{n}=8$, ) and $80 \mu \mathrm{g}$ of buserelin plus $10 \%$ citric acid intravaginally (B80CA, $\mathrm{n}=8$ ). Blood was collected every 15 min from 15 min pretreatment up to $4 \mathrm{~h}$, and then every 30 min up to $6 \mathrm{~h}$ after treatment. $\mathrm{PGF}=\mathrm{PGF}_{2 \alpha}$, TUS $=$ transrectal ultrasonography, $\mathrm{BC}=$ blood collection.

\section{MATERIALS AND METHODS}

\section{Animals}

All procedures were approved by the Animal Care and Use Committee of Cornell University. Lactating Holstein cows from the dairy unit of the Cornell University Ruminant Center (Harford, NY) were used for these experiments, conducted from October 2014 to March 2016. Cows were housed in freestall barns up to the day before intensive blood sample collection, when they were moved to a tiestall barn. Freestall barns were equipped with deep-bedded sand stalls, cooling fans placed above the feeding lane and freestalls, and sprinklers above the feed bunk. The tiestall barn was equipped with deep-bedded wood dust stalls, individual waterers, feed bins, and tunnel ventilation. All cows were fed a TMR diet once daily and had ad libitum access to feed and water. The diet was formulated to meet or exceed nutritional requirements for lactating Holstein cows producing $45 \mathrm{~kg}$ of milk based on the Cornell Net Carbohydrate and Protein System version 6.5 (Department of Animal Science, Cornell University, Ithaca, NY). Cows were milked thrice daily at $\sim 8$-h intervals and received bovine somatotropin (Posilac, 500 mg; Elanco Animal Health, Indianapolis, IN) at 14-d intervals beginning $60 \pm 3$ DIM until dried off.

\section{Treatments}

Experiment 1. Lactating nonpregnant primiparous $(\mathrm{n}=8)$ and multiparous $(\mathrm{n}=31)$ Holstein cows at various DIM were synchronized using the Ovsynch protocol (Pursley et al., 1995) with $2 \mathrm{PGF}_{2 \alpha}$ (25 mg of Lutalyse, Zoetis Animal Health, New York, NY) injections $\left(\mathrm{GnRH}\right.$ at $-7 \mathrm{~d}, \mathrm{PGF}_{2 \alpha}$ at $-1 \mathrm{~d}, \mathrm{PGF}_{2 \alpha}$ at $-32 \mathrm{~h}$, $\mathrm{GnRH}$ at $0 \mathrm{~h}$; Figure 1). At the time of and $48 \mathrm{~h}$ after the second GnRH treatment of Ovsynch, transrectal ultrasonography (TUS) of the ovaries was performed to confirm ovulation, which was defined as the disappearance of at least 1 follicle $\geq 10 \mathrm{~mm}$ and the presence of a putative corpus luteum (CL) on the same ovary. Six cows were excluded because they failed to ovulate after the GnRH treatment. Average $( \pm \mathrm{SD})$ DIM and BCS (scale 1 to 5; Edmonson et al., 1989) for the 6 primiparous and 27 multiparous cows that responded to the synchronization treatment and ovulated were $340 \pm 244 \mathrm{~d}$ and $3.3 \pm 0.7$, respectively.

Seven days after induction of ovulation with the second GnRH treatment of Ovsynch, cows received 2 $\mathrm{PGF}_{2 \alpha}$ treatments $12 \mathrm{~h}$ apart to induce luteal regression. Forty-eight $\mathrm{h}$ after the first $\mathrm{PGF}_{2 \alpha}$ treatment (day $=0$ ), cows were stratified by parity (primiparous vs. multiparous) and DIM and randomly assigned to 1 of 5 treatments: (1) $2 \mathrm{~mL}$ of saline solution IVG (SAL; $\mathrm{n}=$ 6), (2) $100 \mu \mathrm{g}(2 \mathrm{~mL})$ of gonadorelin i.m. in the semimembranosus or semitendinosus muscle (G100-IM; n $=5),(3) 100 \mu \mathrm{g}(2 \mathrm{~mL})$ of gonadorelin IVG $(\mathbf{G 1 0 0} ; \mathrm{n}$ $=7),(4) 500 \mu \mathrm{g}(10 \mathrm{~mL})$ of gonadorelin IVG (G500; $\mathrm{n}=8)$, and (5) $1,000 \mu \mathrm{g}(20 \mathrm{~mL})$ of gonadorelin IVG (G1000; n = 7; Figure 1).

Before application of the IVG treatments, the vulva and perineal area were washed and disinfected with chlorhexidine solution and dried off with paper towels. Thereafter, vulvar labia were manually opened by one 
technician while another technician inserted a uterine infusion catheter $(44.5 \mathrm{~cm}$ long by $0.5 \mathrm{~cm}$ of external diameter) attached to a plastic syringe into the vaginal opening. The catheter was moved cranially until the cervix or vaginal fornix was reached. Once in the cranial portion of the vagina the catheter was pulled backward 1 to $2 \mathrm{~cm}$ and the volume of saline solution or $\mathrm{GnRH}$ analog for the specific treatment was instilled. After treatment, cows remained standing for a minimum of $45 \mathrm{~min}$ to record urination activity and any significant amount of fluid backflow from the vagina.

On d -2 , d 0 (<30 min before treatment), and every $8 \mathrm{~h}$ for up to $48 \mathrm{~h}$ after treatment, the position and size of all antral follicles $\geq 8 \mathrm{~mm}$ in diameter was determined by TUS and recorded for subsequent determination of the occurrence and timing of ovulation after treatment. Timing of ovulation was defined as the midpoint between the last examination in which the putative ovulatory follicle was visualized and the first examination in which the putative ovulatory follicle was not visualized through TUS.

Experiment 2. Lactating nonpregnant multiparous (parity 2 to 5 ) Holstein cows $(\mathrm{n}=59)$ were enrolled and received the synchronization of ovulation protocol described for experiment 1 , except that a different $\mathrm{PGF}_{2 \alpha}$ product was used (Estrumate, Merck Animal Health, Summit, NJ). Average ( \pm SD) DIM, BW, and BCS for the 48 cows that responded to the synchronization treatment and ovulated were $83 \pm 48 \mathrm{~d}, 721 \pm 54 \mathrm{~kg}$, and $3.3 \pm 0.5$ respectively.

At the time of treatment $(\mathrm{d}=0 ; 48 \mathrm{~h}$ after first $\mathrm{PGF}_{2 \alpha}$ treatment following the Ovsynch protocol) cows were randomly assigned to receive 1 of 6 treatments: (1) $2 \mathrm{~mL}$ of saline solution IVG (SAL, $\mathrm{n}=8),(2) 100 \mu \mathrm{g}$ $(2 \mathrm{~mL})$ of gonadorelin i.m. in the semimembranosus or semitendinosus muscle (G100-IM, $\mathrm{n}=8$ ), (3) 1,000 $\mu \mathrm{g}$ $(20 \mathrm{~mL})$ of gonadorelin IVG (G1000, $\mathrm{n}=8)$, (4) 1,000 $\mu \mathrm{g}$ of Gonadorelin plus $10 \%$ citric acid $(20 \mathrm{~mL})$ IVG (G1000CA, n = 8), (5) $80 \mu \mathrm{g}(20 \mathrm{~mL})$ of buserelin IVG $(\mathbf{B} 80, \mathrm{n}=8)$, and (6) $80 \mu \mathrm{g}$ of buserelin plus $10 \%$ citric acid $(20 \mathrm{~mL})$ IVG (B80CA, $\mathrm{n}=8$; Figure 1$)$. The dose selected for buserelin treatment was equivalent to 10 times the recommended dose to induce ovulation in cattle. Treatments were performed following the same procedures described for experiment 1.

To determine if the IVG treatments caused irritation of the vaginal mucosa, on $\mathrm{d}-1$ and $8 \mathrm{~h}$ after treatment the vaginal mucosa was visually inspected using a speculum and a source of light.

\section{GnRH Analog Solutions Used for Treatments}

In experiment 1 , the $\mathrm{GnRH}$ analog gonadorelin (50 $\mu \mathrm{g} / \mathrm{mL}$ of gonadorelin diacetate tetrahydrate, Cystore- lin, Merial LLC, Duluth, GA) was used for the i.m. and IVG treatments. In experiment 2 , gonadorelin was used for the i.m. treatment and either gonadorelin or buserelin were used for the IVG treatments. The same commercially available gonadorelin product was used in experiment 2, whereas buserelin solution (no commercially available product for cattle in the United States) was prepared in our laboratory using buserelin acetate salt (Sigma-Aldrich, Saint Louis, MO). The solution was prepared by adding buserelin and benzyl alcohol (Sigma-Aldrich) to reach a final concentration of $4 \mu \mathrm{g} /$ $\mathrm{mL}$ of buserelin and $9 \mathrm{mg} / \mathrm{mL}$ of benzyl alcohol. Thereafter, the $\mathrm{pH}$ of the solution was adjusted using $\mathrm{NaOH}$ and $\mathrm{HCl}$ to reach a mean $\mathrm{pH}$ of 6.7 . Solutions of gonadorelin and buserelin with citric acid were prepared by adding citric acid (C0759-500G, Sigma-Aldrich) $10 \%$ mass/volume. The final $\mathrm{pH}$ was balanced using $\mathrm{NaOH}$ and $\mathrm{HCl}$ to reach a mean of 4.01 , because an acid $\mathrm{pH}$ has been shown to increase $\mathrm{GnRH}$ absorption by the vagina in rats (Okada et al., 1983). Citric acid was chosen as absorption enhancer because it chelates calcium, which has been shown to loosen intercellular tight junctions, thus facilitating intercellular transport (Cho et al., 1989). In addition, it has been shown that citric acid increases absorption and vaginal permeability of the GnRH analog leuprolide in rats (Okada et al., 1982, 1983).

\section{Blood Sample Collection}

On $\mathrm{d}-7,-2$, and 0 (time of treatment), blood samples were collected from the coccygeal vein or artery using evacuated tubes containing sodium heparin (Vacutainer, BD, Franklin Lakes, NJ) for P4 and estradiol (E2; d 0 only) analysis to confirm response to the synchronization of ovulation protocol, and circulating concentrations of $\mathrm{P} 4$ and $\mathrm{E} 2$ before treatment.

To determine circulating LH concentrations, samples (4 mL) were obtained from the jugular vein using a syringe attached to an indwelling jugular catheter. Samples were collected every $15 \mathrm{~min}$ from $-15 \mathrm{~min}$ to 4 $\mathrm{h}$ after treatment, and every $30 \mathrm{~min}$ from 4 to $6 \mathrm{~h}$ after treatment. Immediately after collection, samples were poured into tubes containing sodium heparin $(10 \mu \mathrm{L}$ of $6.7 \mathrm{IU} / \mathrm{mL}$ of heparin solution) and placed in crushed ice until centrifugation (within $2 \mathrm{~h}$ of collection) for 20 min at $2,000 \times g$ in a refrigerated centrifuge set at $4^{\circ} \mathrm{C}$. After centrifugation, plasma samples were harvested and stored at $-20^{\circ} \mathrm{C}$ until assayed.

Jugular catheters were placed $24 \mathrm{~h}$ before treatment. Briefly, cows were restrained in an individual cow chute and a halter was used to immobilize the head and neck. The area of the neck where the catheter was inserted was shaved using clippers, followed by a first wash with 
povidone iodine solution and a second wash with $70 \%$ ethanol. A 13 gauge $\times 13 \mathrm{~cm}$ long polyurethane catheter over needle (Mila International, France, KY) was inserted into the jugular vein, the needle was removed, and the catheter secured in place using a temporary suture. A 53-cm extension tubing set (Baxter Healthcare Corporation, Deerfield, IL) was attached to the catheter to facilitate sample collection. Sterile saline solution containing $20 \mathrm{IU} / \mathrm{mL}$ of heparin was used to prevent clotting and keep the catheter permeable until sampling began.

\section{Determination of Circulating Concentrations of P4}

Progesterone concentrations were estimated in duplicate using a commercial solid-phase, no-extraction RIA (experiment 1: Coat-a-count, Diagnostic Products Corp., Los Angeles, CA; experiment 2: ImmuChem Coated Tube, MP Biomedicals, Costa Mesa, CA). To assess the precision of the assay, control samples with a high $(7.5$ and $6.0 \mathrm{ng} / \mathrm{mL}$ for experiments 1 and 2, respectively) and low (0.5 and $0.3 \mathrm{ng} / \mathrm{mL}$ for experiments 1 and 2, respectively) concentrations of $\mathrm{P} 4$ were assayed. Average sensitivity for the P4 assay was 0.03 $\mathrm{ng} / \mathrm{mL}$ for experiment 1 and $0.1 \mathrm{ng} / \mathrm{mL}$ for experiment 2 . The intra-assay coefficient of variation for the highconcentration sample was $10.6 \%$ in experiment 1 and $7.9 \%$ in experiment 2 . The coefficient of variation for the low-concentration sample was $4.9 \%$ in experiment 1 and $13.9 \%$ in experiment 2 .

\section{Determination of Circulating Concentrations of E2}

Circulating concentrations of E2 were only determined for samples from experiment 1 because the assay used for experiment 1 was no longer available and no other assay with adequate sensitivity was available to run samples from experiment 2 (collected at a later time). Samples were assayed in duplicate for estimation of E2 concentrations using a double antibody RIA after benzene:toluene extraction. Analysis was performed as described in Beam and Butler (1997) using a commercially available kit (MaiaZen Estradiol R-FA-120, Zen Tech SA, Liege, Belgium). Average sensitivity for the assay was $0.3 \mathrm{pg} / \mathrm{mL}$. A quality control sample $(6.5$ $\mathrm{pg} / \mathrm{mL})$ was added in quadruplicate $(2 \times 100 \mu \mathrm{L}$ and $2 \times 200 \mu \mathrm{L}$ ) at the beginning and end of each assay to assess the precision of the assay; intra-assay coefficient of variation was $16 \%$.

\section{Determination of Circulating Concentrations of $\mathrm{LH}$}

Concentrations of $\mathrm{LH}$ in plasma samples $(200 \mu \mathrm{L})$ from both experiments were determined using 2 dif- ferent double antibody RIA. In experiment 1 , assays $(\mathrm{n}=2)$ were conducted as in Price et al. (1987) with the modifications described in Butler et al. (2004). Samples containing known amounts of LH $(2.5 \mathrm{ng} / \mathrm{mL})$ were included at 3 different dilutions at the beginning and end of each assay. These control samples showed parallelism with the standard curve. Mean limit of detection, defined as $95 \%$ binding, was $0.2 \mathrm{ng} / \mathrm{mL}$; intraand interassay coefficient of variation were 10 and $8 \%$, respectively.

For LH assays used in experiment $2(\mathrm{n}=4)$, bovine LH (bLH AFP-11118B; National Hormone and Peptide Program, Harbor-UCLA Medical Center, Torrance, CA) was used to make iodinated tracer and standards. Rabbit anti-bovine LH antiserum was used as first antibody (AFP-192279; National Hormone and Peptide Program, Harbor-UCLA Medical Center). On d 1, buffer, sample $(200 \mu \mathrm{L})$ or standards, tracer, and first antibody were added to assay tubes and incubated at room temperature for $24 \mathrm{~h}$. On d 2, the secondary antibody was added and incubated at room temperature for $24 \mathrm{~h}$. Thereafter, tubes were incubated at $4^{\circ} \mathrm{C}$ for an additional $24 \mathrm{~h}$. Samples containing high $(4.5 \mathrm{ng} / \mathrm{mL})$ and low $(2.5 \mathrm{ng} / \mathrm{mL}) \mathrm{LH}$ concentrations were included at the beginning and end of each assay at 3 different dilutions. Control samples showed parallelism with the standard curve. Mean limit of detection, defined as $95 \%$ binding, was $0.7 \mathrm{ng} / \mathrm{mL}$ for the 4 assays. The intra-assay coefficient of variation was 9 and $13 \%$ and the interassay coefficient of variation was 9 and $26 \%$ for the high and low control sample, respectively. In both systems the standard curve range was 0.1 to $4 \mathrm{ng}$, which is equivalent to 0.5 to $20 \mathrm{ng} / \mathrm{mL}$.

\section{Statistical Analysis}

Data from experiments 1 and 2 were analyzed using the same methodology unless stated otherwise. A surge of LH after treatment (time 0) was defined as an increase in mean LH concentrations from basal levels (i.e., mean for -15 and 0 min after treatment) equal or greater to the mean increase to maximum concentration in nanograms per milliliter of LH observed for cows in the G100-IM treatment minus 2 standard deviations. This calculation was conducted separately for experiments 1 and 2. Area under the curve (AUC) for LH concentration from -15 to $360 \mathrm{~min}$ after treatment was approximated through the trapezoidal method, as described in Giordano et al. (2012a). For continuous variables (concentrations of $\mathrm{P} 4, \mathrm{E} 2$, and $\mathrm{LH}, \mathrm{AUC}$, maximum LH concentration, time to maximum LH concentration, time to ovulation, DIM, BCS, and BW), normality of residuals and homoscedasticity of variance were verified using graphical methods (Q-Q plot 
and conditional studentized residual plot) generated with the residual option of the MIXED procedure of SAS (version 9.4, SAS Institute Inc., Cary, NC). In both experiments, mean LH concentrations had a nonnormal distribution and studentized residuals showed heteroscedasticity of variance. Because none of the data transformation methods used (natural logarithm, square root, and inverse transformation) eliminated the heteroscedasticity of variance, the natural logarithm of LH concentration was used for experiment 1 and the inverse of LH concentration was used for experiment 2. The final models were selected based on the lowest value for the Akaike information criterion and Bayesian information criterion (Littell et al., 2006). Transformed mean LH concentration values were analyzed using ANOVA with repeated measures using the MIXED procedure of SAS including the Satterthwaite approximation. To adjust for varying intervals in blood sample collection, a spatial power covariance structure was used. Treatment, time, and the treatment by time interaction were included as fixed effects. Cow nested within treatment was included as a random effect in the models.

Data for P4 concentration at time 0, AUC, maximum LH concentration, and time to maximum LH concentration had a non-normal distribution and were transformed to natural logarithm for analysis. The aforementioned variables and BCS, DIM, BW, size of the largest follicle at the time of treatment, and E2 concentration at time 0 were analyzed using ANOVA with the MIXED procedure of SAS with a model that included treatment as fixed effect. The Tukey post-hoc mean separation test was used to determine differences between least squares means. Due to lack of normality and heteroscedasticity of the data, time to ovulation was analyzed using the Kruskal-Wallis test with the NPAR1WAY procedure of SAS, using a model that included treatment as the classification variable.

Binomial outcomes (proportion of cows with a surge of LH and ovulatory response after treatment) were analyzed using Fisher's exact test with the FREQ procedure of SAS because some treatments had either 0 or $100 \%$ of the cows with a positive outcome. Mean separation analysis was not conducted for binomial outcomes because we had an insufficient number of observations for a meaningful comparison.

All values for continuous variables are presented as arithmetical means and SE generated with the MEANS procedure of SAS. All proportions were generated using the FREQ procedure of SAS. All explanatory variables included as fixed effects in models were considered significant if $P<0.05$, whereas $0.05 \leq P \leq 0.10$ were considered a tendency.

\section{RESULTS}

\section{Experiment 1}

No signs of discomfort were observed after treatment in any of the cows. No urination or backflow of fluid from the vagina was observed for up to 45 min after treatment. One cow from the G100 treatment was removed from the data analysis because it presented elevated $\mathrm{P} 4$ $(2.1 \mathrm{ng} / \mathrm{mL})$ concentration at the time of treatment. No statistical difference was observed between treatments for DIM $(P=0.94)$ and BCS $(P=0.46)$.

Size of the Largest Follicle at the Time of Treatment. Size of the largest follicle was not different $(P=0.63)$ among treatments $(\mathrm{SAL}=17.5 \pm 0.6 \mathrm{~mm}$, G100-IM $=16.1 \pm 1.9 \mathrm{~mm}$, G100 $=17.8 \pm 0.3 \mathrm{~mm}$, $\mathrm{G} 500=18.3 \pm 0.7 \mathrm{~mm}$, and $\mathrm{G} 1000=19.1 \pm 2.0 \mathrm{~mm}$ ).

Circulating Concentrations of $\mathrm{P}_{4}$ and E2 at Time 0 . Mean P4 and E2 concentrations at the time of treatment were not different $(P>0.1)$ among treatments (Table 1). All cows had P4 concentrations below $0.5 \mathrm{ng} / \mathrm{mL}$ at time 0 except $1 \mathrm{cow}$ from the SAL and 1 cow from the G100 treatment, which had P4 concentrations of 0.8 and $0.9 \mathrm{ng} / \mathrm{mL}$, respectively.

Circulating Concentrations of LH. Treatment affected $(P<0.001)$ AUC for LH. Cows in the G100IM treatment had the greatest AUC, whereas cows in the G1000 treatment had greater AUC than cows in the SAL and G500 treatments (Table 1). We noted an effect of treatment $(P<0.001)$, time $(P<0.001)$, and treatment by time interaction $(P<0.001)$ for mean circulating LH concentrations (Figure 2).

Treatment affected $(P<0.001)$ the maximum $\mathrm{LH}$ concentration reached during the sampling period. Cows in the G100-IM treatment had the greatest maximum LH concentration, whereas cows in the G1000 treatment had greater maximum LH concentration than cows in the SAL and G500 treatments (Table 1). Treatment affected $(P<0.001)$ the proportion of cows with a surge of LH within $6 \mathrm{~h}$ of treatment. None of the cows in the IVG treatments had an increase in LH concentrations consistent with a surge of $\mathrm{LH}$ as defined for this experiment (Table 1). Time to maximum LH concentration was not compared between treatments because only cows in the G100-IM treatment had a surge of LH.

Ovulatory Response to Treatment. Although our study was not designed to validate treatment effects on binomial outcomes such as ovulatory response, this outcome was recorded and analyzed. Treatment did not affect the proportion of cows that ovulated within $48 \mathrm{~h}$ of treatment $(P=0.28)$ or mean time to ovulation $(P=0.17$; Table 1$)$. 


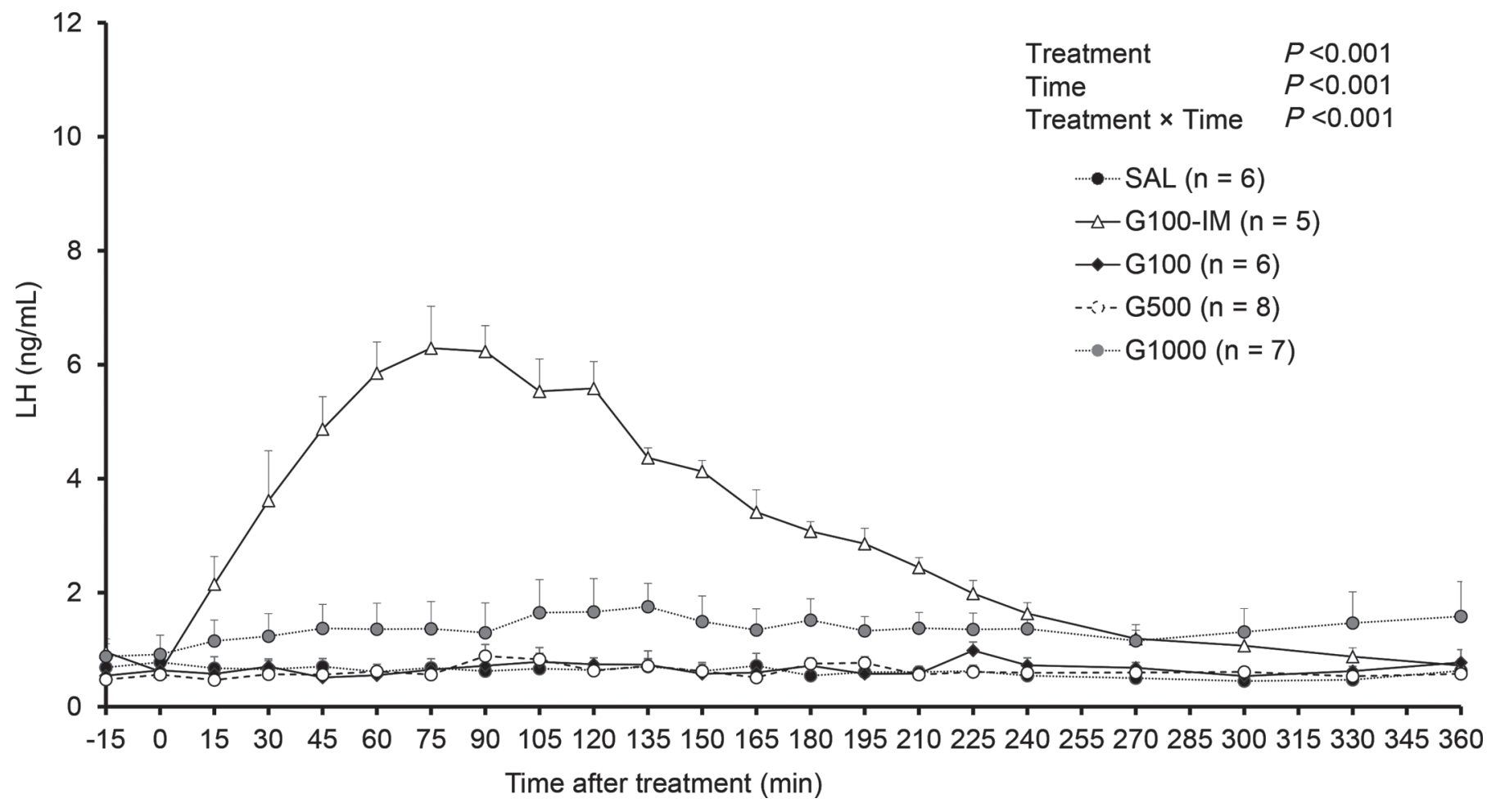

Figure 2. Mean $( \pm \mathrm{SE})$ circulating LH concentrations from $-15 \mathrm{~min}$ to $6 \mathrm{~h}$ after treatment for experiment 1 . Seven days after the second GnRH injection of a modified Ovsynch protocol, cows received $2 \mathrm{PGF}_{2 \alpha}$ treatments $12 \mathrm{~h}$ apart. Forty-eight hours after the first PGF $\mathrm{P}_{2 \alpha}$ treatment, cows were randomly assigned to the following treatments: $\mathrm{SAL}=2 \mathrm{~mL}$ of saline intravaginally (IVG), G100-IM $=100 \mu \mathrm{g}$ of gonadorelin i.m., $\mathrm{G} 100=100 \mu \mathrm{g}$ of gonadorelin IVG, G500 = 500 $\mu \mathrm{g}$ of gonadorelin IVG, G1000 = 1,000 $\mu \mathrm{g}$ of gonadorelin IVG. Blood was collected every 15 min from $15 \mathrm{~min}$ pretreatment up to $4 \mathrm{~h}$, and then every $30 \mathrm{~min}$ up to $6 \mathrm{~h}$ after treatment. There was an effect of treatment $(P<0.001)$, time $(P<0.001)$, and an interaction between treatment and time $(P<0.001)$ on circulating concentration of LH.

Table 1. Steroid hormone concentration (progesterone and estradiol) at the time of treatment, LH secretion dynamics, and ovulation after treatment in experiment 1

\begin{tabular}{|c|c|c|c|c|c|c|c|c|}
\hline Treatment $^{1}$ & $\begin{array}{l}\mathrm{P} 4^{2} \text { time } 0 \\
(\mathrm{ng} / \mathrm{mL})\end{array}$ & $\begin{array}{c}\mathrm{E} 2^{3} \text { time } 0 \\
(\mathrm{pg} / \mathrm{mL})\end{array}$ & $\mathrm{AUC}^{4}$ & $\begin{array}{l}\text { Maximum } \\
\text { LH (ng/mL) }\end{array}$ & $\begin{array}{c}\text { LH surge } \\
(\% ; \text { no. })\end{array}$ & $\begin{array}{l}\text { Time to } \\
\text { maximum } \\
\mathrm{LH}^{5}(\min )\end{array}$ & $\begin{array}{l}\text { Ovulation }^{6} \\
\text { (\%; no.) }\end{array}$ & $\begin{array}{c}\text { Time to } \\
\text { ovulation }^{7}(\mathrm{~h})\end{array}$ \\
\hline SAL $(\mathrm{n}=6)$ & $0.3 \pm 0.1$ & $4.2 \pm 0.9$ & $242 \pm 63^{\mathrm{c}}$ & $1.1 \pm 0.2^{\mathrm{c}}$ & $0(0)$ & - & $67(4)$ & $34 \pm 5$ \\
\hline $\mathrm{G} 100(\mathrm{n}=6)^{8}$ & $0.2 \pm 0.1$ & $4.2 \pm 0.4$ & $286 \pm 36^{\mathrm{bc}}$ & $1.4 \pm 0.2^{\mathrm{bc}}$ & $0(0)$ & - & $50(3)$ & $38 \pm 3$ \\
\hline G500 (n=8) & $0.2 \pm 0.1$ & $4.7 \pm 0.8$ & $247 \pm 55^{\mathrm{c}}$ & $1.2 \pm 0.1^{\mathrm{c}}$ & $0(0)$ & - & $75(6)$ & $36 \pm 5$ \\
\hline $\mathrm{G} 1000(\mathrm{n}=7)$ & $0.1 \pm 0.1$ & $5.4 \pm 1.0$ & $546 \pm 58^{\mathrm{b}}$ & $2.8 \pm 0.6^{\mathrm{b}}$ & $0(0)$ & - & $86(6)$ & $37 \pm 3$ \\
\hline
\end{tabular}

${ }^{\mathrm{a}-\mathrm{c}}$ Different superscripts within a column differ statistically based on Tukey's mean separation test.

${ }^{1}$ Forty-eight hours after the first of $2 \mathrm{PGF}_{2 \alpha}$ treatments given $12 \mathrm{~h}$ apart, cows were randomly assigned to receive the following treatments: 2 $\mathrm{mL}$ of saline intravaginally (SAL), $100 \mu \mathrm{g}$ of gonadorelin i.m. (G100-IM), $100 \mu \mathrm{g}$ of gonadorelin intravaginally (G100), 500 $\mu \mathrm{g}$ of gonadorelin intravaginally (G500), or 1,000 $\mathrm{g}$ of gonadorelin intravaginally (G1000). Blood samples were collected every $15 \mathrm{~min}$ from $-15 \mathrm{~min}$ to $4 \mathrm{~h}$ after treatment and every $30 \mathrm{~min}$ from 4 until $6 \mathrm{~h}$ after treatment.

${ }^{2} \mathrm{P} 4=$ progesterone.

${ }^{3} \mathrm{E} 2=$ estradiol.

${ }^{4} \mathrm{AUC}=$ area under the curve.

${ }^{5}$ Only for cows that had a surge of LH.

${ }^{6}$ Transrectal ultrasonography of the ovaries was performed every $8 \mathrm{~h}$ from time 0 until $48 \mathrm{~h}$ after treatment to detect ovulation.

${ }^{7}$ Standard error of the mean not reported for G100-IM because it was zero.

${ }^{8}$ One cow was removed from the data analysis because it presented elevated $\mathrm{P} 4(2.1 \mathrm{ng} / \mathrm{mL})$ concentration at the time of treatment. 


\section{Experiment 2}

No signs of discomfort or alteration of the vaginal mucosa detectable through visual inspection were observed after treatment in any of the cows. One cow from to the G1000 treatment was removed from the data analysis because $\mathrm{LH}$ concentration at $15 \mathrm{~min}$ before treatment were $889 \%$ greater than the mean of the other cows in the G1000 treatment (6.67 vs 0.75 $\mathrm{ng} / \mathrm{mL}$ ). No statistical difference was observed between treatments for DIM $(P=0.72)$, BW $(P=0.85)$, and BCS $(P=0.98)$.

Circulating Concentrations of $\mathrm{P}_{4}$ at Time of Treatment. No statistical analysis was performed for $\mathrm{P} 4$ concentration at time 0 because mean $\mathrm{P} 4$ concentrations were at or below the assay detection limit (0.1 ng/ $\mathrm{mL}$ ) in all treatments (Table 2). None of the cows had $\mathrm{P} 4$ concentrations above $0.2 \mathrm{ng} / \mathrm{mL}$.

Size of the Largest Follicle at the Time of Treatment. Size of the largest follicle was not different $(P=0.86)$ among treatments $(\mathrm{SAL}=20.5 \pm 1.5 \mathrm{~mm}$, $\mathrm{G} 100-\mathrm{IM}=18.5 \pm 0.5 \mathrm{~mm}, \mathrm{G} 1000=18.6 \pm 0.9 \mathrm{~mm}$, $\mathrm{G} 1000 \mathrm{CA}=19.1 \pm 1.0 \mathrm{~mm}, \mathrm{~B} 80=18.9 \pm 0.6 \mathrm{~mm}$, and $\mathrm{B} 80 \mathrm{CA}=18.9 \pm 1.9 \mathrm{~mm})$.

Circulating LH Concentrations. Treatment affected $(P<0.001)$ the AUC for LH concentrations. The AUC was greater for cows in the G100-IM, G1000CA, and $\mathrm{B} 80 \mathrm{CA}$ treatments than for the other IVG treatments (Table 2). Mean circulating LH concentrations during the experimental period were affected by treatment $(P<0.001)$, time $(P<0.001)$, and the treatment by time interaction $(P<0.001$; Figure 3$)$.
Treatment affected $(P<0.001)$ the proportion of cows that had a surge of LH within the sampling period (Table 2). Treatment affected $(P<0.001)$ maximum LH concentration during the experimental period because it was greater for the G100-IM, G1000CA, and B80CA treatments than for the rest of the IVG treatments (Table 2).

Because no cows in the SAL treatment and only 1 cow in the G1000 and B80 treatments had a surge of $\mathrm{LH}$, these treatments were not included in the analysis of time to maximum LH concentration. Only cows in the G100-IM, G1000CA, and B80CA treatments with an evident LH surge were included in the analysis for time to maximum LH concentration. Treatment affected $(P<0.001)$ time to maximum LH concentration because the G100-IM treatment had the shortest interval from treatment to maximum LH concentration, and the G1000CA had shorter time to maximum LH concentration than the B80CA treatment (Table 2).

Ovulatory Response to Treatment. Although our study was not designed to validly evaluate treatment effects on binomial outcomes, such as ovulatory response, this outcome was recorded and analyzed. Treatment did not affect $(P=0.11)$ the proportion of cows that ovulated within $48 \mathrm{~h}$ of treatment and tended $(P=$ 0.07 ) to affect mean time to ovulation (Table 2).

\section{DISCUSSION}

The main objective of the current research was to test the feasibility of using intravaginal instillation of $\mathrm{GnRH}$ analogs for inducing a surge of $\mathrm{LH}$ in cattle. We

Table 2. Concentration of progesterone at the time of treatment, LH secretion dynamics, and ovulation after treatment in experiment 2

\begin{tabular}{|c|c|c|c|c|c|c|c|}
\hline Treatment $^{1}$ & $\begin{array}{l}\mathrm{P} 4^{2} \text { time } 0 \\
(\mathrm{ng} / \mathrm{mL})\end{array}$ & $\mathrm{AUC}^{3}$ & $\begin{array}{c}\text { LH surge } \\
(\% ; \text { no. })\end{array}$ & $\begin{array}{l}\operatorname{Maximum} \mathrm{LH} / \mathrm{mL}) \\
\end{array}$ & $\begin{array}{l}\text { Time to } \\
\underset{(\min )}{\operatorname{maximum}} \mathrm{LH}^{4}\end{array}$ & $\begin{array}{l}\text { Ovulation }^{5} \\
(\% ; \text { no. })\end{array}$ & $\begin{array}{l}\text { Time to } \\
\text { ovulation }^{6} \\
\text { (h) }\end{array}$ \\
\hline SAL $(\mathrm{n}=8)$ & 0.1 & $356 \pm 36^{\mathrm{b}}$ & $0(0)$ & $1.4 \pm 0.4^{\mathrm{b}}$ & - & $50(4)$ & $38 \pm 6$ \\
\hline $\mathrm{G} 1000(\mathrm{n}=7)^{7}$ & 0.1 & $615 \pm 200^{b}$ & $14(1)$ & $3.1 \pm 1.3^{\mathrm{b}}$ & - & $57(4)$ & $36 \pm 5$ \\
\hline G1000CA $(\mathrm{n}=8)$ & 0.1 & $1,977 \pm 309^{\mathrm{a}}$ & $88(7)$ & $9.8 \pm 1.5^{\mathrm{a}}$ & $145 \pm 5^{\mathrm{b}}$ & $88(7)$ & 28 \\
\hline $\mathrm{B} 80(\mathrm{n}=8)$ & 0.1 & $466 \pm 143^{\mathrm{b}}$ & $13(1)$ & $1.7 \pm 0.6^{\mathrm{b}}$ & - & $88(7)$ & $37 \pm 5$ \\
\hline
\end{tabular}

\footnotetext{
${ }^{\mathrm{a}, \mathrm{b}}$ Different superscripts within a column differ statistically based on Tukey's mean separation test.

${ }^{1}$ Forty-eight hours after the first of $2 \mathrm{PGF}_{2 \alpha}$ treatments given $12 \mathrm{~h}$ apart, cows were randomly assigned to receive the following treatments: 2 mL of saline intravaginally (SAL), $100 \mu \mathrm{g}$ of gonadorelin i.m. (G100-IM), 1,000 $\mu \mathrm{g}$ of gonadorelin intravaginally (G1000), 1,000 $\mu \mathrm{g}$ of gonadorelin plus 10\% citric acid intravaginally (G1000CA), $80 \mu \mathrm{g}$ of buserelin intravaginally (B80), $80 \mu \mathrm{g}$ of buserelin plus $10 \%$ citric acid intravaginally (B80CA). Blood samples were collected every 15 min from - 15 min to $4 \mathrm{~h}$ after treatment and every 30 min from 4 until $6 \mathrm{~h}$ after treatment.

${ }^{2} \mathrm{P} 4=$ progesterone.

${ }^{3} \mathrm{AUC}=$ area under the curve.

${ }^{4}$ Only for cows with a surge of LH in the G100-IM, G100CA, and B80CA treatments.

${ }^{5}$ Transrectal ultrasonography of the ovaries was performed every $8 \mathrm{~h}$ from time 0 until $48 \mathrm{~h}$ after treatment to detect ovulation.

${ }^{6}$ Standard error of the mean for G1000CA and B80CA not reported because it was zero.

${ }^{7}$ One cow was removed from the data analysis because LH concentration at 15 min before treatment were $889 \%$ greater than the mean of the other cows in the treatment (6.67 vs. $0.75 \mathrm{ng} / \mathrm{mL})$.
} 
aimed to induce a surge of $\mathrm{LH}$ similar to that induced after i.m. injection of the labeled dose of GnRH (100 $\mu \mathrm{g}$ of gonadorelin) for synchronization of ovulation in cattle. In experiment 1, 3 different doses of gonadorelin, equivalent to 1,5 , and 10 times the labeled i.m. dose of gonadorelin, were inserted in the vagina of lactating dairy cows. Results from our experiment indicated that IVG instillation of gonadorelin did not elicit a surge of LH of the same magnitude and timing observed after i.m. injection of a $100 \mu \mathrm{g}$ dose of gonadorelin. The lack of response (i.e., no difference from basal LH concentrations up to $6 \mathrm{~h}$ after treatment) to the smaller doses of gonadorelin suggests that either no gonadorelin or less than the minimum amount required to cause a substantial increase in circulating LH concentrations reached the pituitary gland. Conversely, the low magnitude but detectable increase in circulating $\mathrm{LH}$ concentrations observed for cows in the G1000 treatment suggests that at least part of the gonadorelin was absorbed and reached the pituitary gland. Although we cannot rule out the possibility that a surge of LH occurred after sampling concluded, the rate of absorption or the amount absorbed was inadequate to elicit release of large amounts of LH in a surge-like pattern up to the end of the sampling period.

In 2 experiments, Bas et al. (2012, 2014) compared intrauterine administration of 100 or $200 \mu \mathrm{g}$ of gonadorelin with i.m. injection of $100 \mu \mathrm{g}$ of gonadorelin in lactating dairy cows. In both cases, intrauterine administration of gonadorelin failed to mimic the LH surge elicited by i.m. administration. The LH surge observed was of low magnitude and mean LH concentrations did not differ from that of cows that received intrauterine saline. Collectively, the results of our first experiment and others (Bas et al., 2012, 2014) suggest that absorption of gonadorelin through intact vaginal or uterine

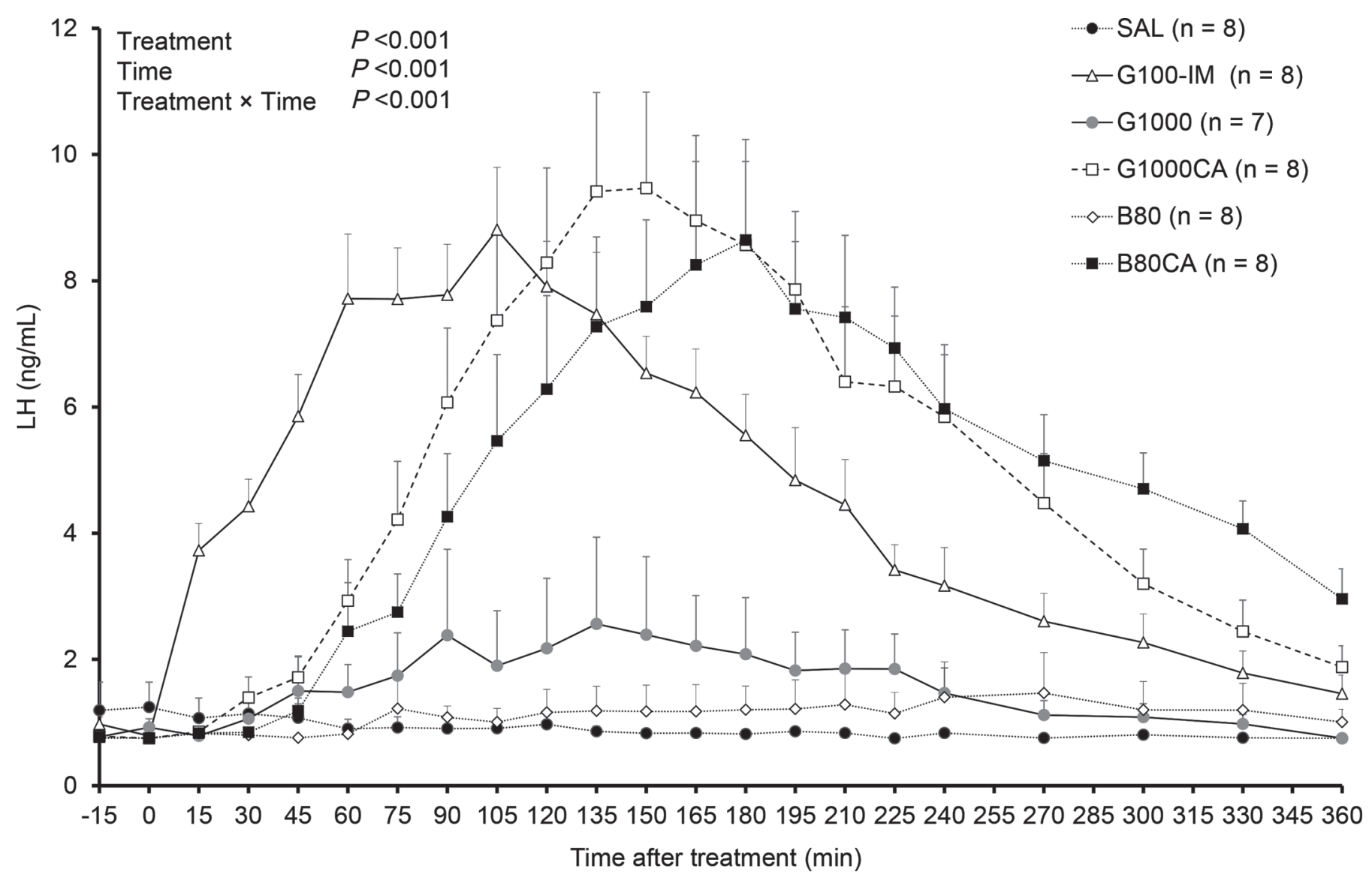

Figure 3. Mean $( \pm \mathrm{SE})$ circulating concentration of LH from -15 min to $6 \mathrm{~h}$ after treatment for experiment 2 . Seven days after the second GnRH injection of a modified Ovsynch protocol, cows received $2 \mathrm{PGF}_{2 \alpha}$ treatments $12 \mathrm{~h}$ apart. Forty-eight hours after the first PGF $2 \alpha$ treatment, cows were randomly assigned to the following treatments: SAL $=2 \mathrm{~mL}$ of saline intravaginally (IVG), G100-IM $=100 \mu \mathrm{g}$ of gonadorelin i.m., $\mathrm{G} 1000=1,000 \mu \mathrm{g}$ of gonadorelin IVG, G1000CA = 1,000 $\mu \mathrm{g}$ of gonadorelin plus 10\% citric acid IVG, B80 = $80 \mu \mathrm{g}$ of buserelin IVG, B80CA = $80 \mu \mathrm{g}$ of buserelin plus $10 \%$ citric acid IVG. Blood was collected every 15 min from 15 min pretreatment up to 4 h, and then every 30 min up to $6 \mathrm{~h}$ after treatment. There was an effect of treatment $(P<0.001)$, time $(P<0.001)$, and an interaction between treatment and time $(P<$ 0.001 ) on circulating concentration of LH. 
epithelium of lactating dairy cows is limited, which, in turn, leads to insufficient absorption of gonadorelin to induce a surge of LH of similar magnitude and timing than that observed after i.m. injection.

By design, the endocrine environment at the time of treatment in cows from experiment 1 was optimal for LH secretion (Giordano et al., 2012a; Lima et al., 2013; Pulley et al., 2015). All cows had subluteal $(<1$ $\mathrm{ng} / \mathrm{mL}$ ) concentrations of $\mathrm{P} 4$ and similar circulating concentrations of E2 to that observed during estrus (Lucy and Stevenson, 1986) when the endogenous LH surge responsible for triggering ovulation is elicited by E2 (Moenter et al., 1990). It is also well known that cattle that receive i.m. GnRH when circulating concentrations of $\mathrm{P} 4$ are low $(<1 \mathrm{ng} / \mathrm{mL})$ and circulating concentrations of E2 are high have greater LH release than when circulating concentrations of P4 are high and E2 concentrations are low (Giordano et al., 2012a; Pulley et al., 2015; Stevenson and Pulley, 2016). In spite of the adequate endocrine environment at the time of treatment, IVG instillation of gonadorelin either did not elicit LH release or the amount released was less than that observed for cows in the i.m. treatment. Only cows in the G1000 treatment had a detectable increase in circulating LH (AUC and maximum LH concentration). Collectively, these observations support the notion that vaginal absorption was substantially less than after i.m. injection and the greater amount of gonadorelin provided to cows in the G1000 treatment only partially offset poor absorption. Because it is unlikely that the pharmacokinetics of a GnRH analog is affected after it reaches the blood stream when given through different routes of administration, we speculated that major reasons for the poor response to IVG treatment with gonadorelin were limited passage through the mucosa, degradation before absorption, or both. Reduced passage (or absorption) may have been the result of the physical barrier created by the intercellular tight junctions of the vaginal epithelium. Degradation of $\mathrm{GnRH}$ analogs is possible because it has been shown that the vaginal mucus from various species (i.e., human, sheep, rat, and rabbit) contains proteolytic enzymes, which may be able to degrade GnRH analogs (Han et al., 1995; Acartürk et al., 2001). Although we cannot completely rule out the possibility of a poor response due to backflow of GnRH, we did not observe backflow from the vagina for up $45 \mathrm{~min}$ after treatment.

Thus, our objective for experiment 2 was to increase absorption of $\mathrm{GnRH}$ analogs through the vaginal mucosa by adding citric acid to the GnRH analog solutions. Increasing absorption of $\mathrm{GnRH}$ analogs was expected to help induce a surge of LH of at least similar in magnitude and timing to that observed after i.m. administration of gonadorelin. In support of our hypothesis, results from experiment 2 provided evidence that including citric acid as an absorption enhancer was a feasible strategy to induce a surge of LH after IVG instillation of GnRH analogs in lactating dairy cows. The addition of citric acid to gonadorelin and buserelin facilitated the induction of a surge of LH in 88 and $100 \%$ of cows in the $\mathrm{G} 1000 \mathrm{CA}$ and $\mathrm{B} 80 \mathrm{CA}$ treatments, respectively. Based on the AUC and maximum LH concentration, the LH surge was of similar magnitude to that observed for cows that received gonadorelin i.m. These findings are in agreement with experiments performed in rats, where vaginal absorption of the GnRH analog leuprolide increased after addition of citric acid (Okada et al., 1982, 1983). Addition of this acid facilitates intercellular transport of peptides, as it loosens intercellular tight junctions by chelating $\mathrm{Ca}^{2+}$ (Cho et al., 1989). In addition, the reduction in $\mathrm{pH}$ may cause alterations to membrane and peptide charges that facilitate absorption of hydrophilic molecules (Okada et al., 1983).

Addition of citric acid benefited absorption of the GnRH analogs; however, the similar magnitude of the LH surge in cows that received $100 \mu \mathrm{g}$ of gonadorelin i.m. and cows in the G1000CA and B80CA treatments suggested that IVG absorption of gonadorelin and buserelin was less efficient than after an i.m. injection of gonadorelin. The treatments that included citric acid also had a clear shift in the timing of LH release, which resulted in greater intervals from treatment to maximum concentration of LH. This interval was at least 30 to 110 min longer than for cows that received gonadorelin i.m. in the present and other experiments (Giordano et al., 2012a; Picard-Hagen et al., 2015; Pulley et al., 2015). This delay may have been the consequence of the additional time required for citric acid to exert its action on the vaginal epithelium. It also suggests that the greatest limitation to absorption of $\mathrm{GnRH}$ analogs was the inability to pass through the mucosa rather than degradation by proteolytic enzymes present in the vaginal mucus.

We also explored the possibility that the potent GnRH analog buserelin would elicit greater LH release than gonadorelin. Our reasoning was that, because of its greater potency [i.e., $\sim 50$ times more potent; (Chenault et al., 1990; Picard-Hagen et al., 2015)], buserelin would be less dependent on absorption of large quantities than gonadorelin. We did not observe a substantial difference in LH concentrations between treatments that received gonadorelin or buserelin with or without citric acid. In fact, the greatest difference in LH profiles between the 2 analogs was the longer interval from treatment to maximum LH concentration in the B80CA treatment. Although this remains speculative, our observations suggest that vaginal absorption of buserelin might have been less efficient than that of 
gonadorelin. Modifications to the molecular structure of buserelin to increase its potency (Millar, 2005) may have been responsible for the reduced absorption or a different response to the reduction in $\mathrm{pH}$.

Our current experiments were not designed to and were underpowered to evaluate ovulatory response to treatment. Nevertheless, the observed incidence and timing of ovulation were intriguing. As expected, all cows with a surge of LH ovulated within $48 \mathrm{~h}$ of treatment, except for 1 cow in the B80CA treatment (data not shown). Interestingly, $64 \%$ of cows that did not have a surge of LH (data combined from experiments 1 and 2) during the sampling period ovulated within 48 $\mathrm{h}$ of treatment. Thus, it is reasonable to speculate that we could have detected more cows with a surge of LH if the sampling period was extended. Whether these LH surges would have been spontaneous or induced by the IVG treatment with the GnRH analogs would have been difficult to determine. The fact that $57 \%$ of the cows in the SAL treatment ovulated suggests that, at least in some cows, a spontaneous and not an induced LH surge occurred after the end of the sampling period. Moreover, although it is rather unlikely, we cannot rule out the possibility that some of these cows had an endogenous LH surge before the time of treatment.

As expected, cows that had a surge of LH during the sampling period tended to ovulate earlier, and timing of ovulation for cows that ovulated in the G100-IM, G1000CA, and B80CA was within the expected time frame after GnRH treatment (Pursley et al., 1995; Rantala et al., 2009; Giordano et al., 2012a). In spite of the fact that cows in the G1000CA and B80CA treatments had a longer interval until LH concentrations reached their peak, mean time to ovulation was the same in all treatments. Therefore, the delay in reaching maximum concentration of LH observed in our experiment may not substantially affect timing of ovulation in cows. Additional research with more cows is necessary to determine if IVG instillation of GnRH analogs leads to differences in ovulatory response and time to ovulation as compared with i.m. injection.

\section{CONCLUSIONS}

Based on results from experiment 1, we concluded that gonadorelin absorption through intact vaginal epithelium was insufficient to elicit a surge of LH of similar magnitude and timing than that observed after i.m. injection of gonadorelin. Based on the results of experiment 2, we concluded that citric acid can enhance absorption of gonadorelin or buserelin through the vaginal mucosa. A dose of gonadorelin and buserelin 10 times greater than the regularly used i.m. dose of these GnRH analogs plus 10\% citric acid induced a surge of
LH of similar magnitude than that induced after i.m. injection of a $100 \mu \mathrm{g}$ dose of gonadorelin. More research is needed to elucidate differences in pharmacokinetics of GnRH and its analogs after IVG administration to establish the most appropriate dose, volume, and vehicle to effectively induce a surge of LH capable of triggering ovulation in cattle. Results from the current experiments and previous research on IVG instillation of $\mathrm{PGF}_{2 \alpha}$ in lactating dairy cows (Wijma et al., 2016) support the potential use of the vagina as a route of administration for reproductive hormones used in synchronization of estrus or ovulation protocols. Demonstrating the feasibility of IVG hormone administration is a necessary first step for facilitating the development of automated IVG hormone delivery devices, which, in turn, might help improve the value of synchronization of estrus and ovulation protocols for cattle operations.

\section{ACKNOWLEDGMENTS}

This material is based upon work that is supported by the National Institute of Food and Agriculture, USDA, Hatch under 1007421 and Multistate 100572 to J. O. Giordano. Any opinions, findings, conclusions, or recommendations expressed in this publication are those of the authors and do not necessarily reflect the view of the National Institute of Food and Agriculture (NIFA) or the USDA. We thank Ron Butler and Susanne Pelton (both from Department of Animal Science, Cornell University, Ithaca, NY) for their help with hormone assays. We also thank personnel from the Dairy Unit of the Cornell University Ruminant Center for helping with cow management.

\section{REFERENCES}

Acartürk, F., Z. I. Parlatan, and Ö. F. Saracoĝlu. 2001. Comparison of vaginal aminopeptidase enzymatic activities in various animals and in humans. J. Pharm. Pharmacol. 53:1499-1504.

Bas, S., M. Maquivar, M. C. da Silva, M. Day, M. Daglio, S. Harguindeguy, M. Titler, and G. M. Schuenemann. 2014. Effect of intrauterine administration of gonadotropin releasing hormone with glycerol on serum LH concentrations in lactating dairy cows. Anim. Reprod. Sci. 145:15-22.

Bas, S., C. Pinto, M. Day, and G. Schuenemann. 2012. Effect of intrauterine administration of gonadotropin releasing hormone on serum LH concentrations in lactating dairy cows. Theriogenology 78:1390-1397.

Beam, S. W., and W. Butler. 1997. Energy balance and ovarian follicle development prior to the first ovulation postpartum in dairy cows receiving three levels of dietary fat. Biol. Reprod. 56:133-142.

Butler, S. T., S. Pelton, and W. Butler. 2004. Insulin increases $17 \beta$-estradiol production by the dominant follicle of the first postpartum follicle wave in dairy cows. Reproduction 127:537-545.

Chebel, R. C., J. Santos, R. Cerri, H. Rutigliano, and R. Bruno. 2006. Reproduction in dairy cows following progesterone insert presynchronization and resynchronization protocols. J. Dairy Sci. 89:4205-4219. 
Chenault, J. R., D. Kratzer, R. Rzepkowski, and M. Goodwin. 1990. LH and FSH response of Holstein heifers to fertirelin acetate, gonadorelin and buserelin. Theriogenology 34:81-98.

Cho, M., J. Scieszka, and P. Burton. 1989. Citric acid as an adjuvant for transepithelial transport. Int. J. Pharm. 52:79-81.

Cross, P. S., R. Künnemeyer, C. R. Bunt, D. A. Carnegie, and M. J. Rathbone. 2004. Control, communication and monitoring of intravaginal drug delivery in dairy cows. Int. J. Pharm. 282:35-44.

Edmonson, A., I. Lean, L. Weaver, T. Farver, and G. Webster. 1989. A body condition scoring chart for Holstein dairy cows. J. Dairy Sci. 72:68-78.

Fatakdawala, H., and S. A. Uhland. 2011. Hydrogen peroxide mediated transvaginal drug delivery. Int. J. Pharm. 409:121-127.

Fricke, P. M., D. Caraviello, K. Weigel, and M. Welle. 2003. Fertility of dairy cows after resynchronization of ovulation at three intervals following first timed insemination. J. Dairy Sci. 86:3941-3950.

Giordano, J. O., P. Fricke, J. Guenther, G. Lopes, M. Herlihy, A. Nascimento, and M. Wiltbank. 2012a. Effect of progesterone on magnitude of the luteinizing hormone surge induced by two different doses of gonadotropin-releasing hormone in lactating dairy cows. J. Dairy Sci. 95:3781-3793.

Giordano, J. O., M. Wiltbank, J. Guenther, R. Pawlisch, S. Bas, A. Cunha, and P. Fricke. 2012b. Increased fertility in lactating dairy cows resynchronized with Double-Ovsynch compared with Ovsynch initiated $32 \mathrm{~d}$ after timed artificial insemination. J. Dairy Sci. 95:639-653.

Han, K., J. S. Park, Y. B. Chung, M. J. Lee, D. C. Moon, and J. R. Robinson. 1995. Identification of enzymatic degradation products of luteinizing hormone releasing hormone (LHRH)/[D-Ala 6] LHRH in rabbit mucosal homogenates. Pharm. Res. 12:1539-1544.

Hussain, A., and F. Ahsan. 2005. The vagina as a route for systemic drug delivery. J. Control. Release 103:301-313.

Ivanov, A. I., A. Nusrat, and C. A. Parkos. 2005. Endocytosis of the apical junctional complex: mechanisms and possible roles in regulation of epithelial barriers. BioEssays 27:356-365.

Künnemeyer, R., P. Cross, C. Bunt, D. Carnegie, and M. Rathbone. 2004. Electronically controlled, intravaginal drug delivery. Proc. Inst. Mech. Eng., B J. Eng. Manuf. 218:1409-1415.

Lamb, G. C., C. Dahlen, J. Larson, G. Marquezini, and J. Stevenson. 2010. Control of the estrous cycle to improve fertility for fixedtime artificial insemination in beef cattle: A review. J. Anim. Sci. 88:E181-E192.

Lima, F. S., E. Ribeiro, R. Bisinotto, L. Greco, N. Martinez, M. Amstalden, W. Thatcher, and J. Santos. 2013. Hormonal manipulations in the 5-day timed artificial insemination protocol to optimize estrous cycle synchrony and fertility in dairy heifers. J. Dairy Sci. 96:7054-7065.

Littell, R. C., W. W. Stroup, G. A. Milliken, R. D. Wolfinger, and O. Schabenberger. 2006. SAS for Mixed Models. SAS Institute Inc., Cary, NC.

Lucy, M. C., and J. S. Stevenson. 1986. Gonadotropin-releasing hormone at estrus: luteinizing hormone, estradiol, and progesterone during the periestrual and postinsemination periods in dairy cattle. Biol. Reprod. 35:300-311.

Macmillan, K., and A. Peterson. 1993. A new intravaginal progesterone releasing device for cattle (CIDR-B) for oestrous synchronisation, increasing pregnancy rates and the treatment of post-partum anoestrus. Anim. Reprod. Sci. 33:1-25.

Macmillan, K., V. Taufa, D. Barnes, and A. Day. 1991. Plasma progesterone concentrations in heifers and cows treated with a new intravaginal device. Anim. Reprod. Sci. 26:25-40.

Millar, R. P. 2005. GnRHs and GnRH receptors. Anim. Reprod. Sci. $88: 5-28$.
Moenter, S. M., A. Caraty, and F. J. Karsch. 1990. The estradiolinduced surge of gonadotropin-releasing hormone in the ewe. Endocrinology 127:1375-1384.

Moreira, F., C. Orlandi, C. Risco, R. Mattos, F. Lopes, and W. Thatcher. 2001. Effects of presynchronization and bovine somatotropin on pregnancy rates to a timed artificial insemination protocol in lactating dairy cows. J. Dairy Sci. 84:1646-1659.

Okada, H., I. Yamazaki, Y. Ogawa, S. Hirai, T. Yashiki, and H. Mima. 1982. Vaginal absorption of a potent luteinizing hormone-releasing hormone analog (leuprolide) in rats I: Absorption by various routes and absorption enhancement. J. Pharm. Sci. 71:1367-1371.

Okada, H., I. Yamazaki, T. Yashiki, and H. Mima. 1983. Vaginal absorption of a potent luteinizing hormone-releasing hormone analogue (leuprolide) in rats II: Mechanism of absorption enhancement with organic acids. J. Pharm. Sci. 72:75-78.

Picard-Hagen, N., G. Lhermie, S. Florentin, D. Merle, P. Frein, and V. Gayrard. 2015. Effect of gonadorelin, lecirelin, and buserelin on LH surge, ovulation, and progesterone in cattle. Theriogenology 84:177-183.

Price, C. A., B. Morris, and R. Webb. 1987. Reproductive and endocrine effects of active immunization against a testosterone conjugate in the heifer. J. Reprod. Fertil. 81:149-160.

Pulley, S. L., D. Keisler, and J. Stevenson. 2015. Concentrations of luteinizing hormone and ovulatory responses in dairy cows before timed artificial insemination. J. Dairy Sci. 98:6188-6201.

Pursley, J. R., M. Mee, and M. Wiltbank. 1995. Synchronization of ovulation in dairy cows using PGF $2 \alpha$ and GnRH. Theriogenology 44:915-923.

Pursley, J. R., M. Wiltbank, J. Stevenson, J. Ottobre, H. Garverick, and L. Anderson. 1997. Pregnancy rates per artificial insemination for cows and heifers inseminated at a synchronized ovulation or synchronized estrus. J. Dairy Sci. 80:295-300.

Rantala, M. H., O. Peltoniemi, T. Katila, and J. Taponen. 2009. Effect of GnRH dose on occurrence of short oestrous cycles and LH response in cyclic dairy heifers. Reprod. Domest. Anim. 44:647-652.

Rathbone, M. J., K. L. Macmillan, K. Inskeep, S. Burggraaf, and C. R. Bunt. 1998. Fertility regulation in cattle. J. Control. Release $54: 117-148$.

Richardson, J. L., and L. Illum. 1992. (D) Routes of delivery: Case studies:(8) The vaginal route of peptide and protein drug delivery. Adv. Drug Deliv. Rev. 8:341-366.

Souza, A. H., H. Ayres, R. Ferreira, and M. Wiltbank. 2008. A new presynchronization system (Double-Ovsynch) increases fertility at first postpartum timed AI in lactating dairy cows. Theriogenology 70:208-215.

Stevenson, J. S., and S. Pulley. 2016. Feedback effects of estradiol and progesterone on ovulation and fertility of dairy cows after gonadotropin-releasing hormone-induced release of luteinizing hormone. J. Dairy Sci. 99:3003-3015.

Stewart, K. R., W. Flowers, G. Rampacek, D. Greger, M. Swanson, and H. Hafs. 2010. Endocrine, ovulatory and reproductive characteristics of sows treated with an intravaginal GnRH agonist. Anim. Reprod. Sci. 120:112-119.

Viudes-de-Castro, M. P., R. Lavara, F. Marco-Jiménez, C. Cortell, and J. Vicente. 2007. Ovulation induced by mucosa vaginal absorption of buserelin and triptorelin in rabbit. Theriogenology 68:1031-1036.

Wijma, R., M. Stangaferro, and J. Giordano. 2016. Circulating progesterone dynamics after intravaginal instillation of prostaglandinF2 $\alpha$ to lactating dairy cows. Theriogenology 85:1660-1668.

Wiltbank, M. C., and J. R. Pursley. 2014. The cow as an induced ovulator: Timed AI after synchronization of ovulation. Theriogenology 81:170-185. 